Article

\title{
Characterization, Biocompatibility, and Optimization of Electrospun SF/PCL/CS Composite Nanofibers
}

\author{
Hua-Wei Chen *(D) and Min-Feng Lin \\ Department of Chemical and Materials Engineering, National Ilan University, Yilan 26047, Taiwan; \\ superlemi@gmail.com \\ * Correspondence: hwchen@niu.edu.tw
}

Received: 9 March 2020; Accepted: 25 June 2020; Published: 27 June 2020

\begin{abstract}
In this study, composite nanofibers (SF/PCL/CS) for the application of dressings were prepared with silk fibroin (SF), polycaprolactone (PCL), and chitosan (CS) by electrospinning techniques, and the effect of the fiber diameter was investigated using the three-stage Taguchi experimental design method (L9). Nanofibrous scaffolds were characterized by the combined techniques of scanning electron microscopy (SEM) and transmission electron microscopy (TEM), a cytotoxicity test, proliferation tests, the antimicrobial activity, and the equilibrium water content. A signal-to-noise ratio $(\mathrm{S} / \mathrm{N})$ analysis indicated that the contribution followed the order of SF to PCL $>$ flow rate $>$ applied voltage $>$ CS addition, possibly owing to the viscosity and formation of the beaded fiber. The optimum combination for obtaining the smallest fiber diameter $(170 \mathrm{~nm})$ with a smooth and uniform distribution was determined to be a ratio of SF to PCL of 1:2, a flow rate of $0.3 \mathrm{~mL} / \mathrm{hr}$, and an applied voltage of $25 \mathrm{kV}$ at a needle tip-to-collector distance of $15 \mathrm{~cm}$ (position). The viability of these mouse fibroblast L929 cell cultures exceeded $50 \%$ within 24 hours, therefore $\mathrm{SF} / \mathrm{PCL} / \mathrm{CS}$ could be considered non-toxic according to the standards. The results proposed that the hydrophilic structure of SF/PCL/CS not only revealed a highly interconnected porous construction but also that it could help cells promote the exchange of nutrients and oxygen. The SF/PCL/CS scaffold showed a high interconnectivity between pores and porosity and water uptake abilities able to provide good conditions for cell infiltration and proliferation. The results from this study suggested that SF/PCL/CS could be suitable for skin tissue engineering.
\end{abstract}

Keywords: chitosan; composite nanofibers; electrospinning; silk fibroin; polycaprolactone; Taguchi

\section{Introduction}

In recent decades, nanofiber membranes have been widely used in various fields and attracted more attention due to their unique properties, such as large specific surface areas, high porosity, interconnected pores, and high functionality. Electrospun composite nanofibers possess great potentialities in biomedical applications, such as tissue engineering [2-4], wound healing [5-7], and drug delivery [8-10], as well as other applications such as magnetism [11], photonics [12], filtration [13], composites [14], shape memory [15], and lithium batteries [16]. The diameter of electrospun nanofibers affects many important properties, such as the melting point, tensile modulus, hardness, drug delivery, biological factors, and cell growth of nonwoven fabrics [17,18]. Research [19] has demonstrated that fiber diameter plays a key role in cell adhesion, proliferation, and cell migration on the scaffold.

Silk fibroin (SF), which is extracted mainly from silkworms, has various properties, including good biocompatibility, biodegradability, morphological flexibility, mechanical properties, a low inflammatory response, non-toxicity, and non-carcinogenicity, and it can promote cell adhesion, migration, and the proliferation of cell ligands $[8,20,21]$. However, the $\beta$-sheet secondary structure of pure SF seems to impede the electrospinning process, and the mechanical properties of neat $\mathrm{SF}$ electrospun fibers were 
poor [20]. Herein, polycaprolactone (PCL), the most commonly used synthetic polymer, was chosen to be blended with SF. PCL is widely used in tissue engineering and drug delivery applications due to its good mechanical properties and biodegradability. PCL has limitations to its biological activity, hydrophobicity, and bacterial degradation, therefore PCL cannot provide the adhesion environment required for cells [2]. PCL has renowned mechanical properties and does not have ionizable side groups in its structures, such as $-\mathrm{COOH}$ and $-\mathrm{NH}_{2}$, which occur on the natural polymer chitosan (CS) and on several anionic polysaccharides and proteins, respectively. The CS is an amino polysaccharide derived from chitin that has excellent biological properties, such as biocompatibility, biodegradability, hydrophilicity, non-toxicity, and antithrombotic and antimicrobial activities. Chitosan that possesses positively charged groups (amine groups) is likely to interact with negatively charged cell membranes via electrostatic interaction. Furthermore, the antimicrobial activity of chitosan effectively increases the permeability of negatively charged cell membranes to disrupt and release intracellular compounds [22]. Therefore, investigations of SF and its association with other components (PCL and CS) are carried out to give better mechanical properties to the smooth nanofibers for the tissue engineering. The Taguchi method is an effective method to find the influence of different factors on the target results, thereby improving the manufacturability, reliability, and quality of a product and reducing the number of experiments and calculation time $[23,24]$

Thus, SF/PCL/CS composite nanofiber scaffolds for the application of dressings and tissue engineering were fabricated with PCL polymer as a precursor using electrospinning techniques in this study. Further, the effect of chitosan additions on the nanofiber diameter was also investigated via the analysis of the antimicrobial activity and equilibrium water content. The optimum combination of parameters obtained from the ratio of silk fibroin to polycaprolactone, chitosan additions, flow rate, and applied voltage in response to minimizing diameter size and its variation for SF/PCL/CS composite nanofibers was determined by means of the Taguchi DoE method. Herein, the biocompatible properties were evaluated with cytotoxicity tests and proliferation tests so as to determine the optimal SF/PCL/CS scaffolds.

\section{Experimental Method}

\subsection{Preparation of Regenerated Silk Fibroin (SF)}

All the materials, solvents, and reagents were purchased from commercial suppliers and used as received. Cocoons were received from Paolun farm (Taiwan). Polycaprolactone (PCL, Mw $=80,000)$ was purchased from Sigma-Aldrich (St. Louis, MO). Polyethylene oxide (PEO, Mw = 60,000-100,000), chitosan (CS, Mw = 10,000-30,000), and formic acid were purchased from Acros Organics. The preparation of the silk fibroin (SF) used in this study made reference to previous research [1], with some modification. The cocoons were boiled in a $0.5 \%(\mathrm{w} / \mathrm{v}) \mathrm{Na}_{2} \mathrm{CO}_{3}$ aqueous solution at a temperature of $100{ }^{\circ} \mathrm{C}$ for one hour. The silk fibers were rinsed with distilled water for $30 \mathrm{~min}$ to remove the $\mathrm{Na}_{2} \mathrm{CO}_{3}$ aqueous solution and then rinsed with deionized water for $30 \mathrm{~min}$ to remove the sericin. After being dried to a constant weight in an oven at $80^{\circ} \mathrm{C}$, the degummed silk fibers were dissolved in $40 \%$ aqueous $\mathrm{CaCl}_{2}$ at $100^{\circ} \mathrm{C}$. The SF solution was replaced with a dialyzed membrane (molecular weight cut-off $(\mathrm{MWCO})=12,000-14,000 \mathrm{Da})$ for three days to eliminate small molecular impurities and calcium chloride. Lastly, the SF solution was lyophilized in a freeze dryer and stored at room temperature.

\subsection{Preparation of the Electrospinning Solutions and Electrospinning}

The SF and PCL were dissolved in formic acid to obtain $10 \mathrm{wt} . \%$ concentrations. Different ratios of SF/PCL (5.00\%:5.00\%, 3.33\%:6.67\%, and 2.50\%:7.50\%) were dissolved in formic acid and stirred at room temperature for two hours. Subsequently, $1 \mathrm{wt} . \% \mathrm{PEO}$ as a thickener was added to the solution. Finally, from 0.5 to $1 \mathrm{wt} . \%$ CS was added to the electrospinning solutions. 
The SF/PCL/CS composite nanofibers were obtained from the electrospinning of the prepared suspensions through a FES-COS electrospinning apparatus (Falco Co, Taipei, Taiwan). Briefly, the suspensions were drawn into a $10 \mathrm{~mL}$ syringe with a 21-gauge needle. The electrospinning was performed under ambient conditions (a temperature of 24.5 to $27.5{ }^{\circ} \mathrm{C}$ and a relative humidity of $45 \%$ to $50 \%$ ). The following optimized electrospinning parameters were kept constant throughout the experiments: $100 \mathrm{rpm}$ roller collector to collect fibers, $15 \mathrm{~cm}$ TCD (tip to collector distance), $15 \mathrm{kV}-25 \mathrm{kV}$ applied voltage, and $0.2 \mathrm{~mL} / \mathrm{h}-0.4 \mathrm{~mL} / \mathrm{h}$ feeding rate. The SF/PCL/CS homogeneous solutions were electrospun on a rotating cylindrical drum covered with an aluminum layer during the process. Finally, the collected membranes were taken from the surface of the collector and conserved in a sealed container for further experiments.

\subsection{Taguchi DOE Parameter Setting}

Numerous references [19-24] state that the ratio of silk fibroin to polycaprolactone, the chitosan content, the flow rate, and the applied voltage have significant effects on the average diameter and uniformity of fibers; thus, these four concentration and electrospinning parameters were selected for this experiment (Table 1).

Table 1. Actors and levels used in the experiment.

\begin{tabular}{ccccc}
\hline & $\begin{array}{c}\text { Ratio of Silk Fibroin } \\
\text { and Polycaprolactone }\end{array}$ & $\begin{array}{c}\text { Chitosan Content } \\
\text { (wt. \%) }\end{array}$ & $\begin{array}{c}\text { Flow Rate } \\
\text { (mL/h) }\end{array}$ & Voltage (kV) \\
\hline Level 1 & $1: 1(5.00 \%: 5.00 \%)$ & 0.50 & 0.2 & 15 \\
Level 2 & $1: 2(3.33 \%: 6.67 \%)$ & 0.75 & 0.3 & 20 \\
Level 3 & $1: 3(2.50 \%: 7.50 \%)$ & 1.00 & 0.4 & 25 \\
\hline
\end{tabular}

The full factorial experiment of $81\left(3^{4}\right)$ trials could be completed in just 27 runs due to the slope collector; however, that would entail a large number of tests, which would be significant in both experimental cost and time. As a result, the Taguchi design of experiments (DoE) layouts were more applicable when compared to a traditional full-factorial counterpart because they reduced the number of tests to a practical level. The L9 DoE orthogonal array was selected with the assumption of no factorial interactions, resulting in nine trials, as illustrated in Table 2.

Table 2. Experimental results of the fiber fineness of the composite nanofibers planned by the $\mathrm{L}_{9}\left(3^{4}\right)$ orthogonal table.

\begin{tabular}{|c|c|c|c|c|c|c|c|c|}
\hline $\mathrm{L}_{9}\left(3^{4}\right)$ & $\begin{array}{l}\text { Ratio } \\
\text { (SF: } \\
\text { PCL) }\end{array}$ & $\begin{array}{c}\text { Chitosan } \\
\text { Addition } \\
(\%)\end{array}$ & $\begin{array}{l}\text { Flow } \\
\text { Rate } \\
(\mathrm{mL} / \mathrm{h})\end{array}$ & $\begin{array}{c}\text { Voltage } \\
\text { (kV) }\end{array}$ & $\mathrm{S} / \mathrm{N}$ & $\begin{array}{c}\text { Means of } \\
\text { Diameter (nm) }\end{array}$ & $\begin{array}{l}\text { Porosity } \\
(\%)\end{array}$ & $\begin{array}{c}\text { WVTR } \\
\left(\mathrm{g} \mathrm{m}^{-2} \cdot 24 \mathrm{~h}\right)\end{array}$ \\
\hline 1 & $1: 1$ & 0.50 & 0.2 & 15 & 12.65 & $232.55 \pm 60.28$ & $88.01 \pm 4.32$ & $4417.29 \pm 87.27$ \\
\hline 2 & $1: 1$ & 0.75 & 0.3 & 20 & 12.71 & $229.09 \pm 60.66$ & $83.10 \pm 4.21$ & $4362.97 \pm 91.67$ \\
\hline 3 & $1: 1$ & 1.00 & 0.4 & 25 & 13.61 & $208.39 \pm 55.81$ & $91.96 \pm 5.16$ & $4641.38 \pm 19.21$ \\
\hline 4 & $1: 2$ & 0.50 & 0.3 & 25 & 15.37 & $170.00 \pm 55.76$ & $92.05 \pm 3.70$ & $4768.71 \pm 85.04$ \\
\hline 5 & $1: 2$ & 0.75 & 0.4 & 15 & 11.92 & $253.42 \pm 65.37$ & $91.43 \pm 5.50$ & $4636.29 \pm 25.46$ \\
\hline 6 & $1: 2$ & 1.00 & 0.2 & 20 & 13.11 & $220.67 \pm 62.13$ & $85.37 \pm 4.04$ & $4432.89 \pm 45.84$ \\
\hline 7 & $1: 3$ & 0.50 & 0.4 & 20 & 10.86 & $285.71 \pm 78.08$ & $92.60 \pm 4.10$ & $4581.97 \pm 92.58$ \\
\hline 8 & $1: 3$ & 0.75 & 0.2 & 25 & 11.47 & $266.75 \pm 76.71$ & $84.74 \pm 5.70$ & $4330.71 \pm 5.09$ \\
\hline 9 & $1: 3$ & 1.00 & 0.3 & 15 & 12.68 & $231.94 \pm 63.64$ & $82.03 \pm 1.45$ & $4405.41 \pm 74.86$ \\
\hline
\end{tabular}

In the "larger the better" characteristic, the formula for calculating the ratio of $\mathrm{S} / \mathrm{N}$ as the best parameter for calculating the factors was calculated by the following Equation (1):

$$
\mathrm{S} / \mathrm{N}=-10 \times \log \left(\frac{1}{n} \sum_{i=1}^{n} \frac{1}{y_{i}^{2}}\right)
$$


where $\mathrm{n}$ and $\mathrm{y}$ denote the number of measurements and observed data, respectively.

\subsection{Characterization of Nanofiber Scaffolds}

The morphology of the nanofiber scaffold was detected using scanning electron microscopy (SEM; TS 5136MM, TESCAN, Czech Republic). The average fiber diameter was determined by measuring 100 fibers selected randomly from each sample. Chemical analysis was performed using a Fourier transform infrared spectrometer (FTIR; Spectrum 100, Perkin Elmer, USA) with a scan range of 4000 to $450 \mathrm{~cm}^{-1}$ and an accumulation of 16 scans.

According to standard method of Japanese Industrial Standards (JIS) 10099A, the water vapor transmission rate (WVTR) is a measure of the passage of water vapor through a substance. In addition to measurements of the permeability of the vapor barriers, the porosity of the SF/PCL/CS was also examined by the study [25]. For the antibacterial assay, the inhibitory effects of chitosan on bacterial growth were detected by the plate well diffusion method [26] via the formation of a zone of inhibition. To attain this figure, the sequential dilution was necessary (six for E. coli and for S. aureus) according to the simultaneous counting of plate colonies (CFU). The procedure used in this analysis followed the agar diffusion method according to the previous literature [27], in which small circular cavities were punctured in the culture medium for each chitosan concentration.

The equilibrium water content (EWC) was measured by the conventional gravimetric method. The pre-weighed dry samples were immersed in deionized water, and the excess surface water was blotted out with absorbent paper. The swelling procedure was repeated until there was no further weight increase. The EWC was calculated as the weight increase with respect to the weight of the swollen samples within $24 \mathrm{~h}$ using the following Equation (2):

$$
E W C=\frac{W_{\text {wet }}-W_{\text {dry }}}{W_{\text {wet }}} \times 100 \%
$$

where $W_{\text {wet }}$ and $W_{\text {dry }}$ denote the weights of the swollen and dry samples, respectively.

A cytotoxicity assay is a test for analyzing the cytotoxic effects of materials and medical devices on living organisms [28]. The following cell culture-based tests, as recommended by ISO 10993-5, used a direct contact test. In all the tests (blank, negative control, positive control, and sample), the incubation time of the mouse fibroblast L929 cell cultures was $24 \mathrm{~h}$. Cell culture is the process by which cells from human tissue are grown in an incubator under controlled conditions in order to provide sufficient material for testing. After solubilization, the solutions were transferred to fresh flat bottom 96-well plates, and the absorbance $(570 \mathrm{~nm})$ of each well was measured by spectrophotometry. The background absorbance at $650 \mathrm{~nm}$ was subtracted from the readings at $570 \mathrm{~nm}$ to obtain the final optical density (OD). The following Equation (3) was used to calculate the reduction in the culture viability of the cells exposed to a tested sample (i.e., SF/PCL/CS under optimal conditions) in comparison to the cell culture viability of group b:

$$
\text { Viability }(\%)=\frac{O D_{570 e}}{O D_{570 b}} \times 100 \%
$$

where $O D_{570 e}$ is the average OD of the respective groups that were in contact with different lots of the product and $O D_{570 b}$ is the average OD of all the wells of group b. All the values were final ODs after the subtraction of background absorbance. 


\section{Results and Discussion}

\subsection{Optimum Combination of Factors for the Application of Dressings}

\subsubsection{Taguchi Method to Optimize Dressings}

Uniform fiber diameters and smaller diameters in the scaffold for the application of dressings can provide a higher surface area and interconnected holes to promote the exchange of nutrients and oxygen and enhance the proliferation ability of cells. In the formation of nanofibers, the ratio of silk fibroin to polycaprolactone, the chitosan content, the flow rate, and the voltage are crucial factors affecting the nanofiber diameter. In Taguchi designed experiments, the higher values of the signal-to-noise ratio $(\mathrm{S} / \mathrm{N})$ identify control factor settings that minimize the effects of the noise factors. Using the Equation (1) of the smaller the better method (i.e., the smallest diameter of the nanofibers was selected based on maximum $\mathrm{S} / \mathrm{N}$ ratio), the $\mathrm{S} / \mathrm{N}$ ratio of the fiber fineness (the diameter of the nanofibers) in the SEM micrograph of the nanofiber could be calculated, and the results are shown in Table 2. According to the results from the $\mathrm{L}_{9}\left(3^{4}\right)$ sample, the average $\mathrm{S} / \mathrm{N}$ ratio of the four factor levels was calculated to perform the next analysis, as listed in Table 3. The influence of the four factors on the fiber diameter followed the order of the ratio of silk fibroin and polycaprolactone $(\Delta=1.80)>$ flow rate $(\Delta=1.46)>$ applied voltage $(\Delta=1.26)>$ chitosan addition $(\Delta=1.10)$. This finding suggested that the ratio of silk fibroin and polycaprolactone was the most significant factor for achieving a small electrospun nanofiber diameter for the application of dressings. Table 3 also shows the contribution of the four parameters to the influence of the SF/PCL/CS composite nanofiber diameter. The ratio of the silk fibroin and polycaprolactone was an important factor affecting the diameter of the nanofibers due to the highest contribution percentage $(32.0 \%)$. Furthermore, the results indicated that the ratio of silk fibroin and polycaprolactone affected the viscosity of the electrospinning solution to produce a stable Taylor cone. The results were in accordance with the Taguchi experimental S/N design.

Table 3. Smaller the better of the fiber fineness signal-to-noise ratio $(\mathrm{S} / \mathrm{N})$ analysis.

\begin{tabular}{ccccc}
\hline & $\begin{array}{c}\text { Ratio of Silk Fibroin and } \\
\text { Polycaprolactone }\end{array}$ & Chitosan Content & Flow Rate & Voltage \\
\hline 1 & 12.99 & 12.96 & 12.41 & 12.42 \\
\hline 2 & 13.47 & 12.03 & 13.59 & 12.23 \\
\hline 3 & 11.67 & 13.13 & 12.13 & 13.48 \\
\hline$\Delta$ & 1.80 & 1.10 & 1.46 & 1.26 \\
\hline Factor influence order & 1 & 4 & 2 & 3 \\
\hline Contribution $(\%)$ & 32.0 & 19.1 & 26.2 & 22.7 \\
\hline
\end{tabular}

The average value of the confirmation experiments was $170.00 \pm 55.76 \mathrm{~nm}$ under the optimal parameters of a silk fibroin to polycaprolactone ratio of 1:2, a chitosan addition of $0.5 \%$, a rate of advancement of $0.3 \mathrm{~mL} / \mathrm{h}$, and an operating voltage of $25 \mathrm{kV}$ (Table 2), which provided the highest average value compared with the nine groups of quality data. As shown in Figures 1 and 2, the results indicated that the optimal parameters inferred by the Taguchi method had a smaller fiber diameter, were smoother, and had a low distribution. Conclusively, the comparison of the optimal parameters inferred by the Taguchi method with the data results of the orthogonal table proved that the inferred optimal parameters were appropriate. 


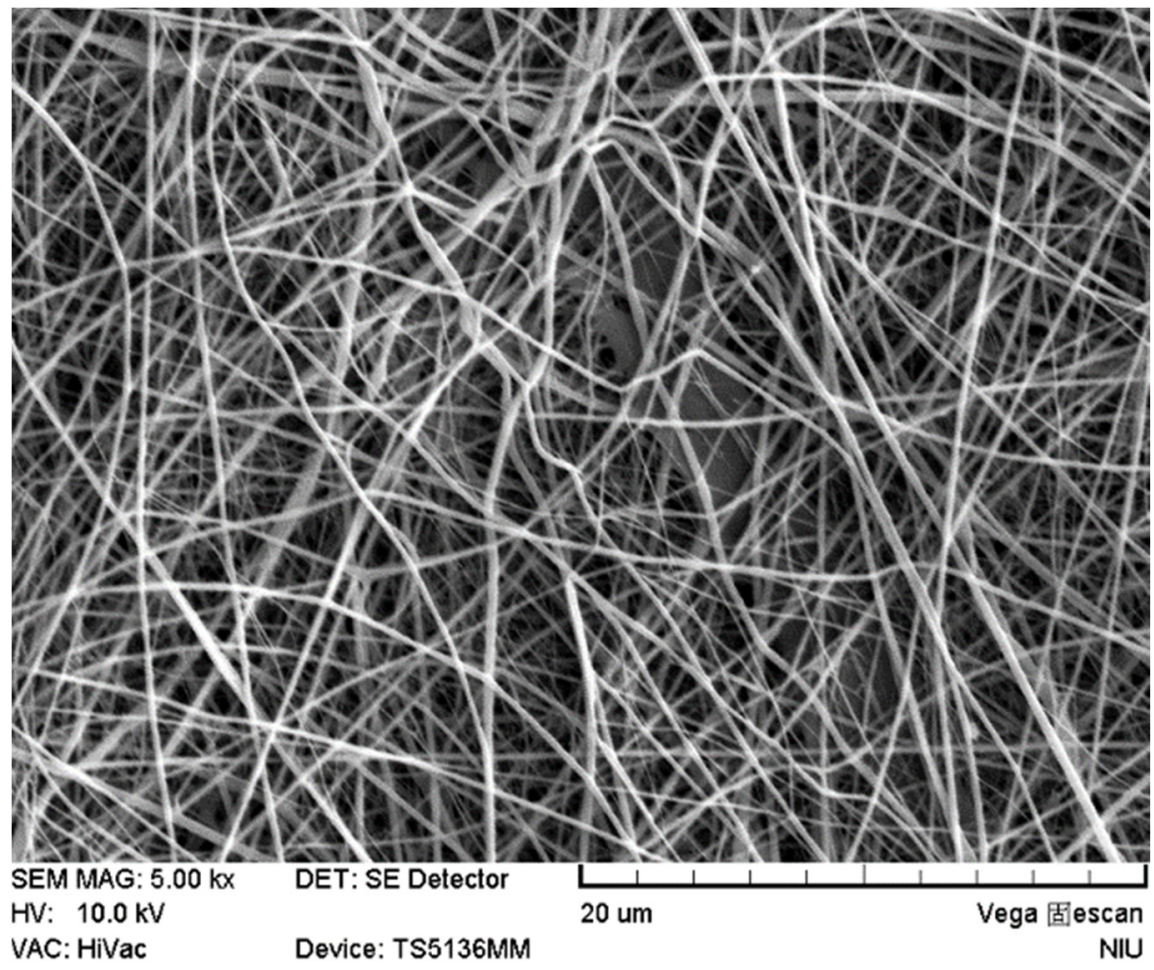

Figure 1. SEM photomicrograph of the silk fibroin (SF), polycaprolactone (PCL), and chitosan (CS) (SF/PCL/CS) nanofibers under optimal conditions.

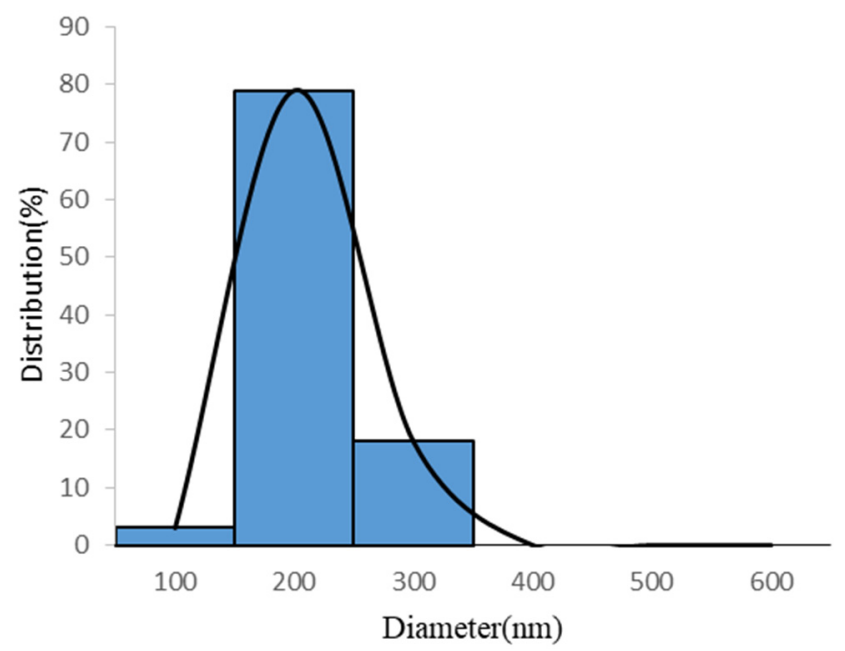

Figure 2. Fiber diameter distribution of the SF/PCL/CS nanofibers under optimal conditions.

\subsubsection{Porosity and Water Uptake Abilities}

The adequate pore size and interconnected pores of a scaffold provides a sufficient opportunity for cell migration and proliferation. The ability of a dressing to control water loss can be determined by the water vapor transmission rate (WVTR). The ability of a scaffold to preserve water is also important in order to evaluate its property for tissue engineering. Table 2 describes the WVTR of the SF/PCL/CS nanofibers. The porosity of the nine samples $\left(\mathrm{L}_{9}\left(3^{4}\right)\right)$ of the SF/PCL/CS nanofibers in this study was more than $80 \%$ and was significantly higher than the pure PCL scaffolds, which had a $70 \%$ porosity, as reported by [29]. The highly porous SF/PCL/CS nanofibers could provide an appropriate environment for initial cell growth (by their structural stability), accelerated degradation (by their large surface area), and the sustained delivery of bioactive molecules (by their high porosity). 
In this study, SF/PCL/CS nanofibers with graded WVTR were prepared by changing the porosity of the membrane (Table 2). The corresponding average WVTR of the samples was in the range of between 4330.71 and $4768.71 \mathrm{~g} \mathrm{~m}^{-2} .24 \mathrm{~h}$ (extremely high permeability, $\mathrm{L}_{9}\left(3^{4}\right)$ ). An extremely high WVTR may lead to the dehydration of a wound, whereas an unacceptably low WVTR may cause the accumulation of wound exudates. Hence, a dressing with a suitable WVTR is required to provide a moist environment that can establish the best environment for natural healing. Thus, a dressing prepared by optimal condition with a WVTR of approximately $4768.71 \mathrm{~g} / \mathrm{m}^{2} \cdot 24 \mathrm{~h}$ could also maintain the optimal moisture content for the proliferation and function of cells and fibroblasts. According to SEM and the appropriate porosity of the SF/PCL/CS nanofiber, it was considered to have great potential for skin tissue engineering due to its interconnected pore network and suitable WVTR.

\subsubsection{Cytotoxicity Tests}

Cytotoxicity assays are necessary for the assessment and characterization of the potentially toxic and harmful effects of a biomaterial's compounds [28]. They are a feasible and reliable in vitro technique used for the biocompatibility evaluation of materials. Table 4 shows phase contrast images of the cultures in the experiment after $24 \mathrm{~h}$, including blank, negative control (polyethylene, PE), positive control (dimethylsulfoxide, DMSO), and SF/PCL/CS under optimal conditions. In cultures exposed to blank, negative control, positive control, and SF/PCL/CS, the viability was 100, 100, 13, and $57 \%$ at $24 \mathrm{~h}$ of continued growth in the culture, respectively. A tested product (SF/PCL/CS) has non-cytotoxic potential for application to tissue engineering when the cell culture viability increases to $>50 \%$ in comparison to the positive control (dimethylsulfoxide, DMSO), which was set at a $13 \%$ viability. The study also proposed the similar results that the tested product could be considered non-toxic as the viability of these cultures exceeded 50\% [30]. Furthermore, the viability of $57 \%$ for the tested product (SF/PCL/CS) in this study was higher than that of $50.2 \%$ for the CNTs-doped PLGA nanofibers [31]. The research [31] show that the PLGA and the HNTs- or CNTs-doped PLGA nanofibers display appreciable MTT formazan dye sorption, corresponding to a 35.6-50.2\% deviation from the real cell viability assay data. From Figure 3, the DMSO treatment substantially altered the morphology and attachment of cells in concurrence with a significant reduction in the cell viability. The results showed that the electrospun scaffolds (SF/PCL/CS) could support the attachment and the proliferation of mouse fibroblast L929 cells. In addition, the cells cultured on the scaffolds exhibited normal cell shapes. The obtained results confirmed the potential for use of the electrospun fiber as scaffolds for skin tissue engineering.

Table 4. Viability of cell L 929 according to the MTT test method.

\begin{tabular}{ccc}
\hline Test Item & Absorbance (\%) & Viability (\%) \\
\hline Blank & $0.504 \pm 0.011$ & 100 \\
Negative control & $0.502 \pm 0.005$ & 100 \\
Positive control & $0.064 \pm 0.002$ & 13 \\
Sample (SF/PCL/CS) & $0.288 \pm 0.020$ & 57 \\
\hline
\end{tabular}




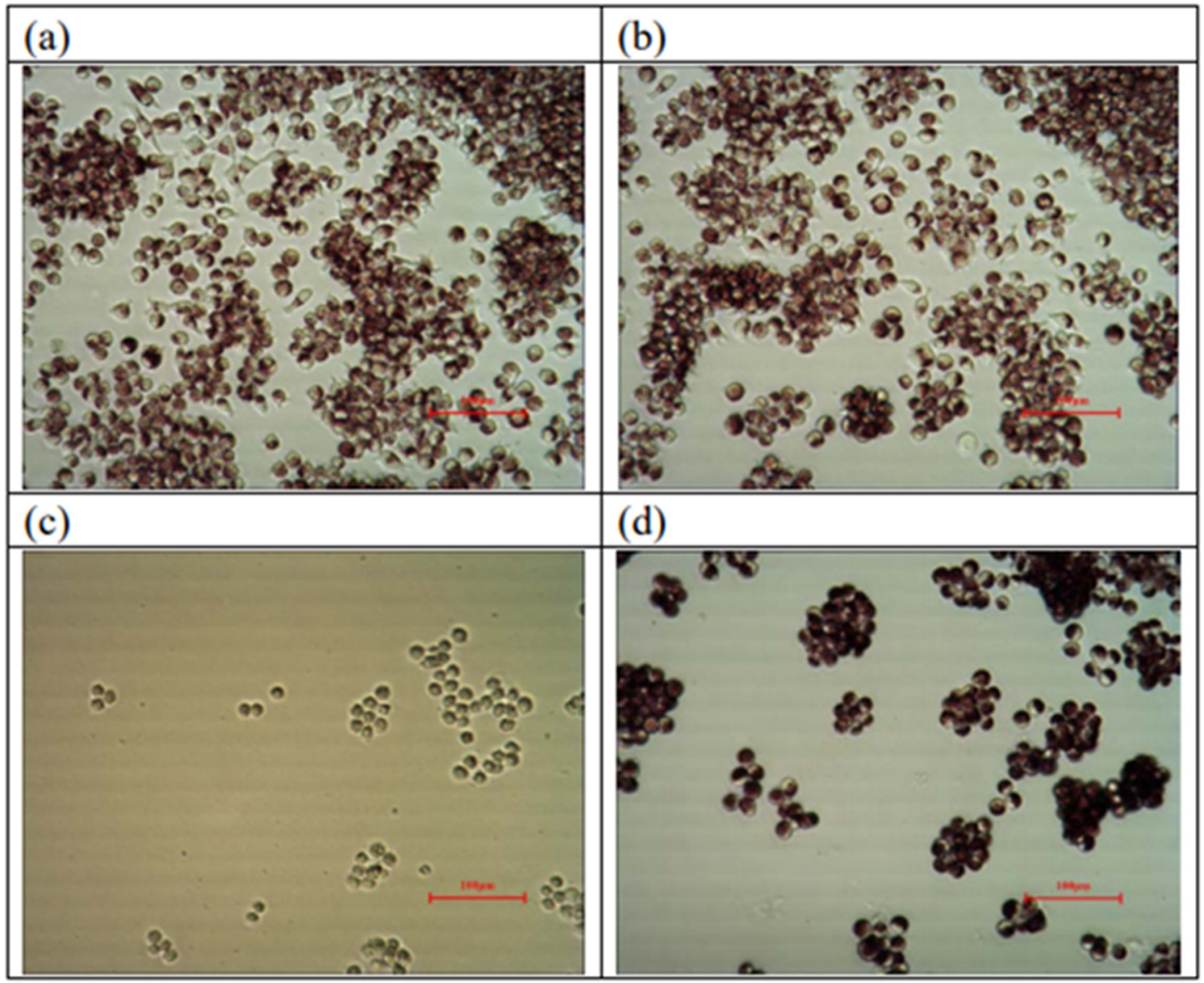

Figure 3. Photomicrograph of cell L 929 by direct contact method within 24 hours: (a) blank; (b) negative control (polyethylene, PE); (c) positive control (dimethylsulfoxide, DMSO); and (d) the sample (SF/PCL/CS under optimal conditions).

\subsection{Effect of the Ratio of Silk Fibroin to Polycaprolactone on Fiber Diameter}

In the electrospinning process, the solution concentration is considered to be the most important parameter affecting the fiber morphology [31,32]. Figure 4 shows the effect of the ratio of silk fibroin to polycaprolactone on the fiber diameter. At a silk fibroin to polycaprolactone ratio of 1.0, the entanglement between the polymer chains formed obvious beads because the low viscosity of the solution did not provide a stable jet. As the ratio of silk fibroin to polycaprolactone decreased from 0.5 to 0.25 , the average fiber diameter increased from $208.27 \pm 68.27 \mathrm{~nm}$ to $664.23 \pm 131.54 \mathrm{~nm}$ in this study. The main reason was that the increase in viscosity hindered the bending stability of the jet to produce a coarser fiber $[33,34]$. 


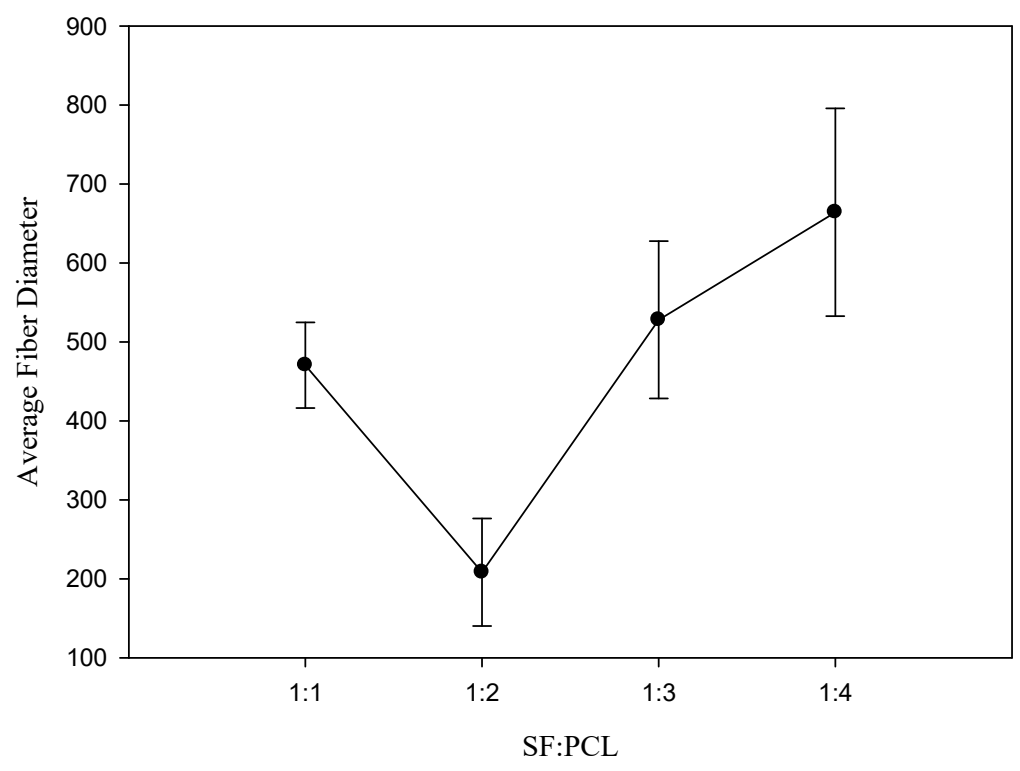

Figure 4. Effect of the ratio of silk fibroin to polycaprolactone on the fiber diameter.

\subsection{Effect of Chitosan Addition on Fiber Diameter, Antimicrobial Activity, and Equilibrium Water Content}

Figure 5 depicts the evaluation results of the fiber diameter of the electrospinning scaffold with different chitosan additions. The average fiber diameter decreased from $523.23 \pm 92.60 \mathrm{~mm}$ to $181.45 \pm 41.57 \mathrm{~nm}$ with the increased chitosan addition from $0.25 \%$ to $1.00 \%$ because of the charge density. The chitosan addition enhanced the higher charge density of the jet to produce the thinner fibers due to the increase in conductivity [21,35]. Compared to the chitosan addition of $1.00 \%$, the average fiber diameter of the electrospinning scaffold was increased to $308.90 \pm 74.98 \mathrm{~nm}$ with a chitosan addition of $1.50 \%$, because the increase in viscosity caused the bending instability of the jet and the accelerating solidification of the polymer jet $[34,36]$.

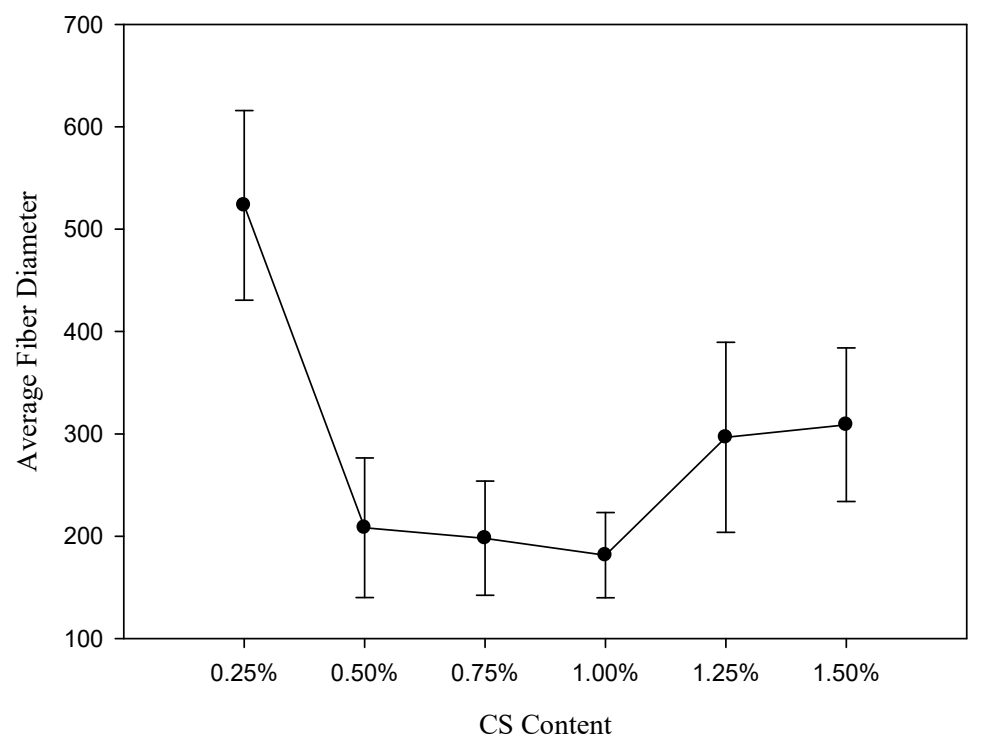

Figure 5. Effect of the chitosan addition on the fiber diameter.

The results from Table 5 revealed the mean diameter of inhibition zone for E. coli with the chitosan amounts of $0.25 \%, 0.5 \%, 0.75 \%$, and $1.00 \%$ were $65,63,64$, and $63 \mathrm{~mm}$, respectively, proving the strong antibacterial property. Moreover, the samples with the chitosan amounts of $0.25 \%, 0.5 \%, 0.75 \%$, and $1.00 \%$ exhibited the inhibition zone diameters for $S$. aureus of $58,55,51$, and $55 \mathrm{~mm}$, respectively. As 
illustrated in Figures 6 and 7, the activity intensity could be visually determined by agar well diffusion assay testing via assessing the local inhibition. The results of the experiments conducted using different chitosan additions had an inhibitory effect on the mean diameter of the inhibition zone for two types of bacteria (E. coli and S. aureus). The results exhibited better inhibitory effects against gram-positive bacterium S. aureus compared to the gram-negative bacterium E. coli., which was in agreement with the results attained in previously published works [37,38]. The results in this study proposed that unmodified chitosan generally acts stronger on gram-negative strains than on gram-positive strains, owing to the electrostatic interaction between positively charged $\mathrm{R}-\mathrm{N}\left(\mathrm{CH}_{3}\right)_{3}{ }^{+}$sites and negatively charged microbial cell membranes.

Table 5. Effect of chitosan addition on the mean diameter of the inhibition zone of E. coli and S. aureus at different chitosan amounts.

\begin{tabular}{cccc}
\hline \multirow{2}{*}{$\begin{array}{c}\text { Name of the Sample } \\
\text { Conc. (\%) }\end{array}$} & \multicolumn{2}{c}{$\begin{array}{c}\text { Mean Diameter of Inhibition Zone (mm) } \\
\text { Test Organisms }\end{array}$} \\
\cline { 3 - 4 } & & Staphylococcus Aureus & Escherichia Coli \\
\hline \multirow{2}{*}{ Chitosan } & 0.25 & $58 \pm 4$ & $65 \pm 0$ \\
& 0.50 & $55 \pm 1$ & $63 \pm 4$ \\
& 0.75 & $51 \pm 1$ & $64 \pm 0$ \\
& 1.00 & $55 \pm 1$ & $63 \pm 2$ \\
\hline
\end{tabular}

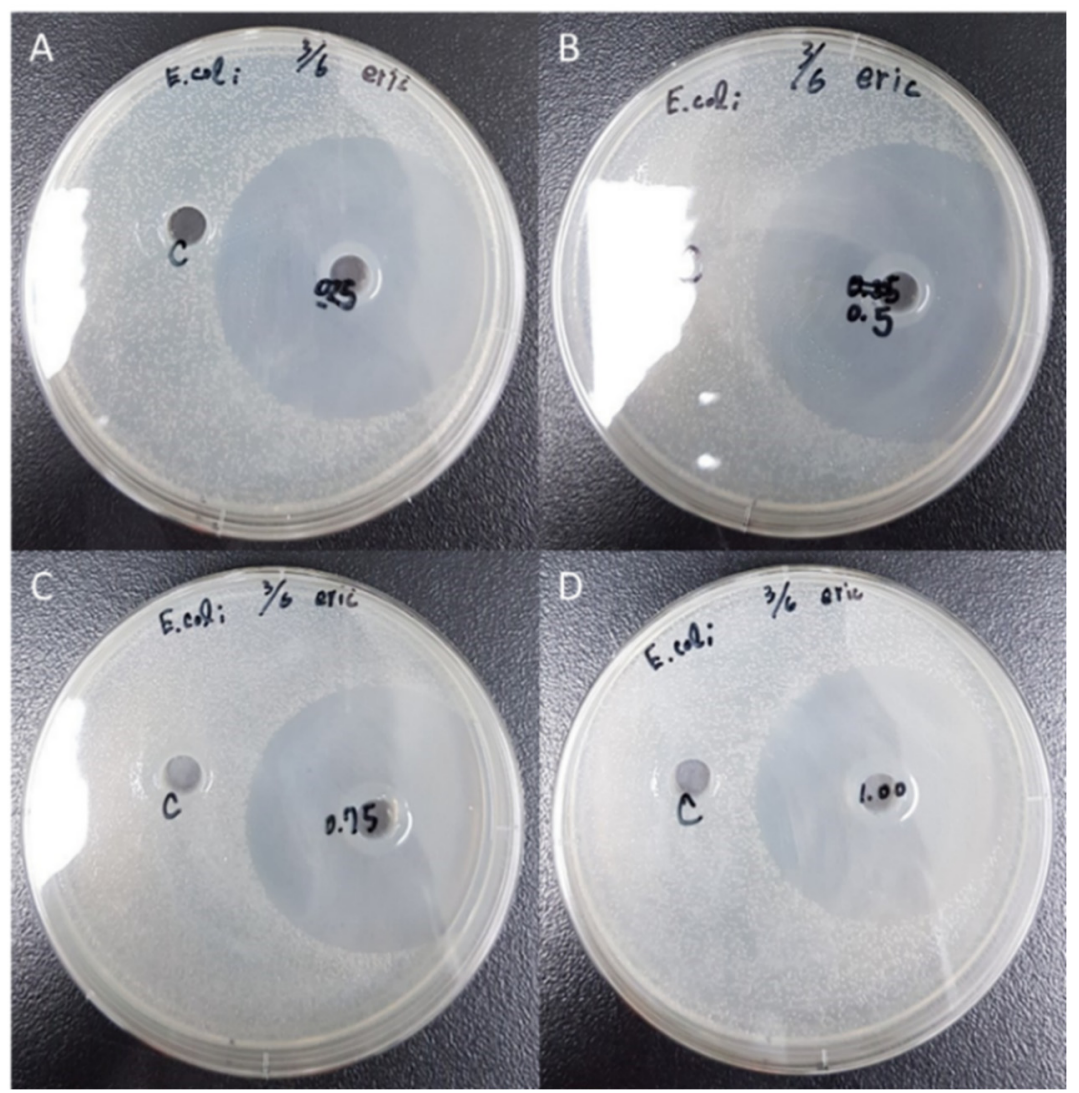

Figure 6. Effect of the chitosan addition on the antimicrobial activity of E. coli at different chitosan amounts: (A) 0.25 ; (B) 0.50; (C) 0.75 ; (D) $1.00 \mathrm{wt} \%$. 


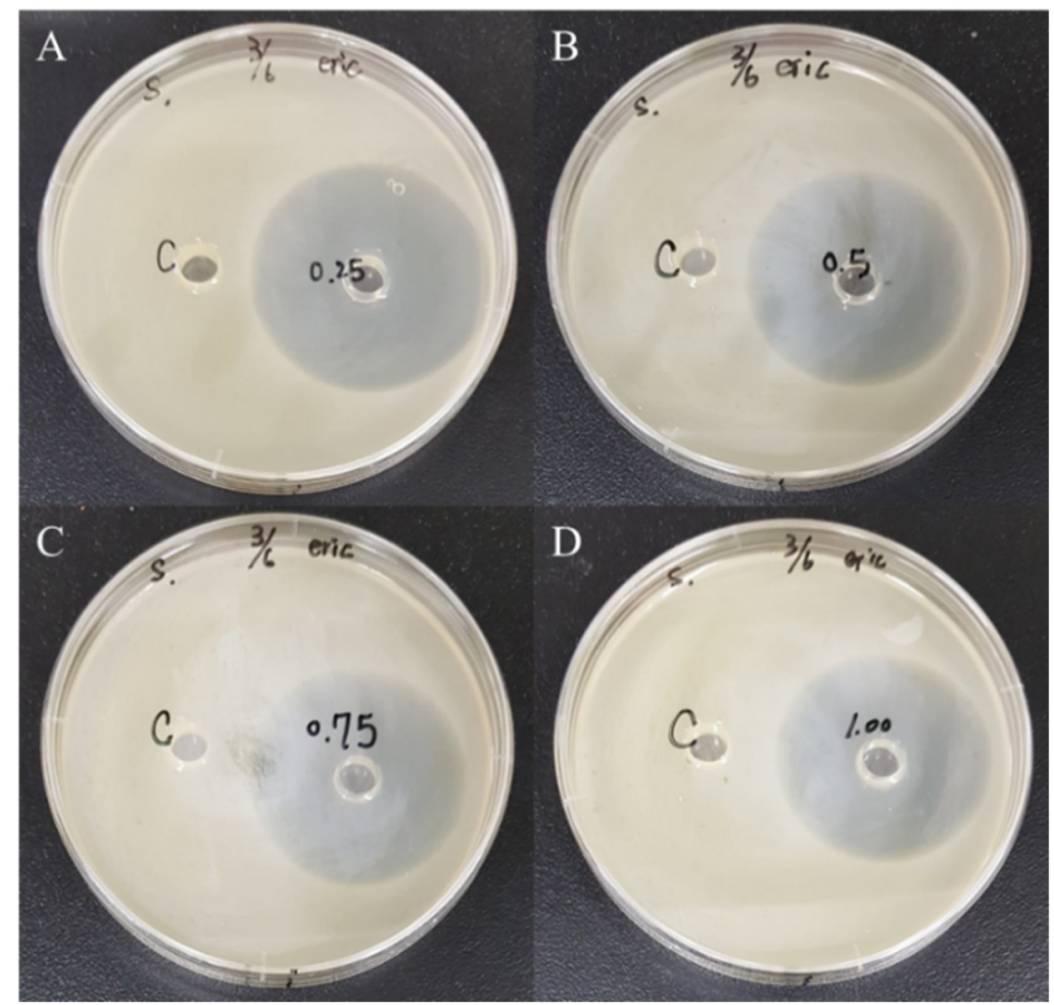

Figure 7. Effect of chitosan addition on the antimicrobial activity of $S$. aureus at different chitosan amounts: (A) 0.25 ; (B) 0.50; (C) 0.75 ; (D) $1.00 \mathrm{wt} \%$.

The hydrophilicity of nanofibers (SF/PCL/CS) with different chitosan additions $(0.25 \%, 0.50 \%$, $0.75 \%$, and $1.00 \%$ ) was measured by gravimetric analysis and designated by the percentage equilibrium water content (EWC), as shown in Figure 8. The EWC was increased with the increasing chitosan addition due to the functional groups of $-\mathrm{OH}$ and $-\mathrm{NH}_{2}$. The equilibrium water content (EWC) of all the nanofibers (chitosan additions of $0.25 \%, 0.50 \%, 0.75 \%$, and $1.00 \%$ ) was in the range of $500 \%$ to 950\% and was significantly higher than the YY0148-2006 standard for medical dressings [39] and the hydrogels for tissue engineering [40]. The copolymerization with the zwitterionic comonomer leads hydrogels with a high equilibrium water content (EWC) of up to $700 \%$ while maintaining mechanical robustness [40].

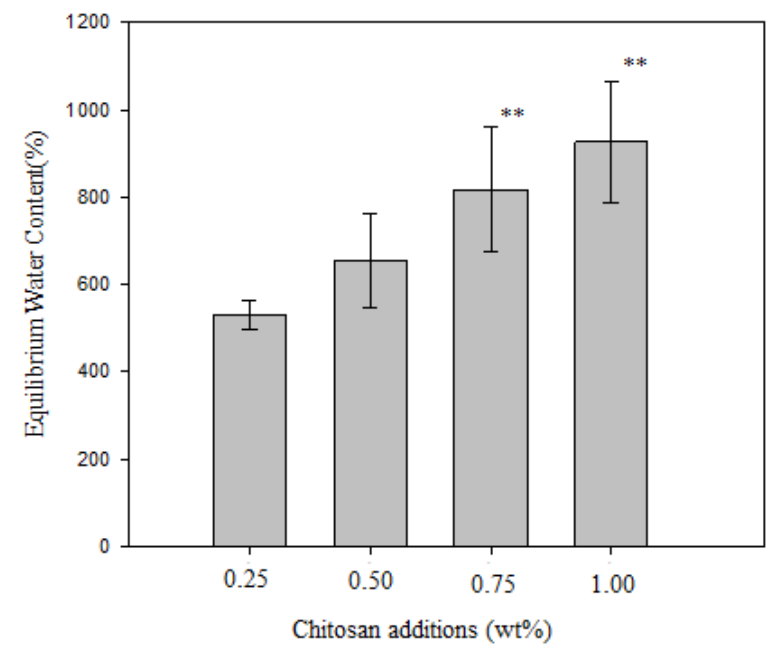

Figure 8. Effect of chitosan addition on the equilibrium water content. 


\subsection{Effect of Flow Rate on Fiber Diameter}

In the electrospinning process, the flow rate is considered to be the most important parameter affecting the fiber uniformity [31,41]. The effect of the flow rate on the fiber diameter is shown in Figure 9a. As shown in Figure 9b, uniform beadless electrospun nanofibers were prepared via a critical flow rate of $0.3 \mathrm{~mL} / \mathrm{h}$ for the polymeric solution. The shape of the Taylor cone at the tip of the capillary would not be maintained if the flow of the solution through the capillary was insufficient, and the insufficient intermolecular surface tension would be unable to resist the Coulomb force to maintain a stable jet [41]. However, at a higher flow rate, the solution would be wasted without differentiating adequately into the fibers. The short evaporation time of the solvent could result in the formation of beads and increase the average fiber diameter [32]. The morphology of the SF/PCL/CS nanofibers appeared to be inhomogeneous under a higher flow rate, as depicted in Figure 9c. The results could be explained by the inharmony between the fiber formation speed and the solution feed rate.

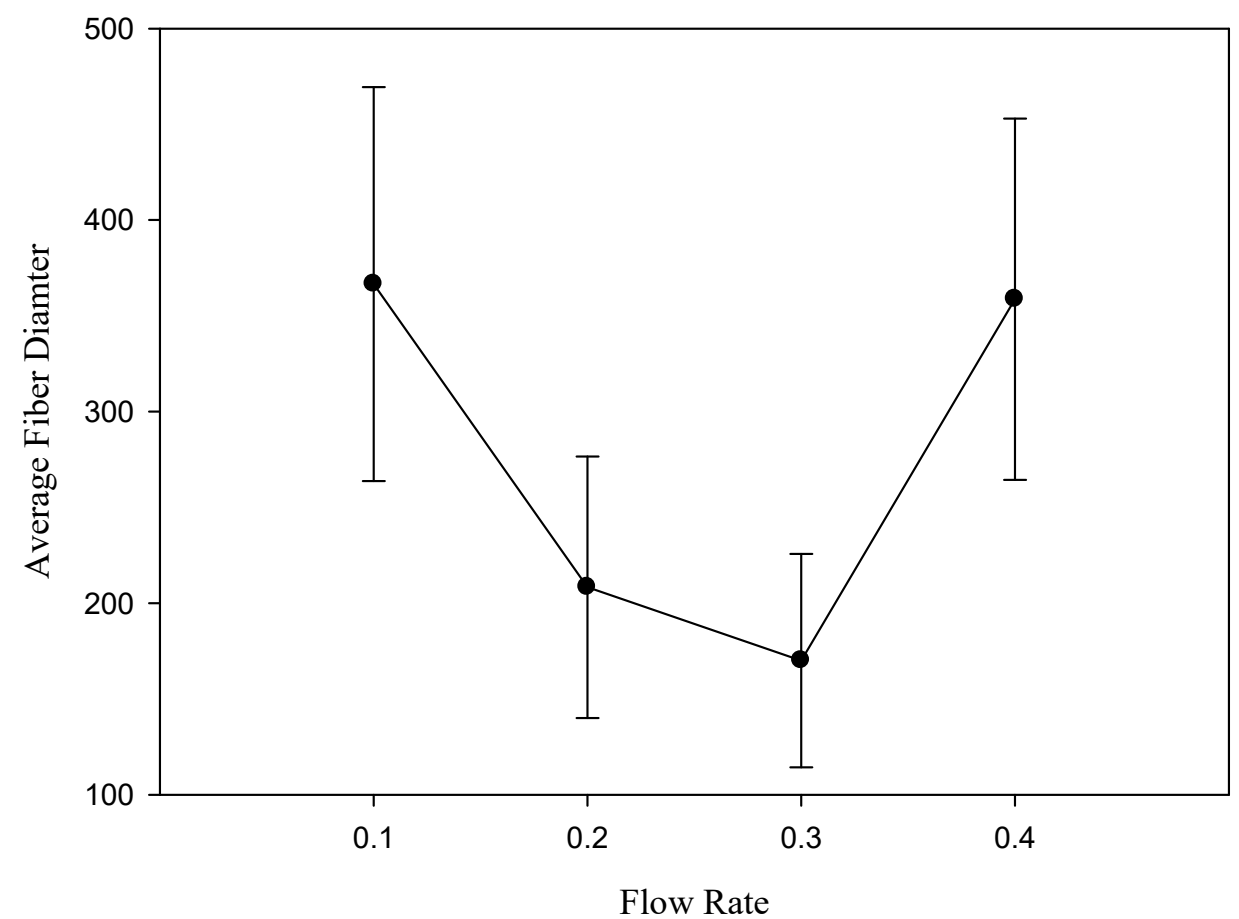

(a)

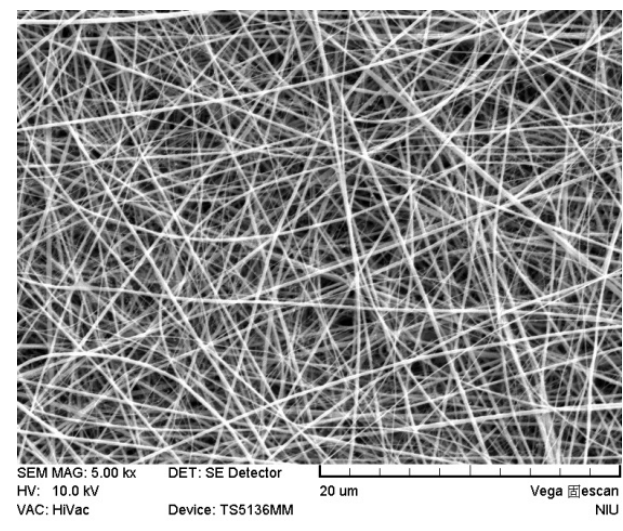

(b)

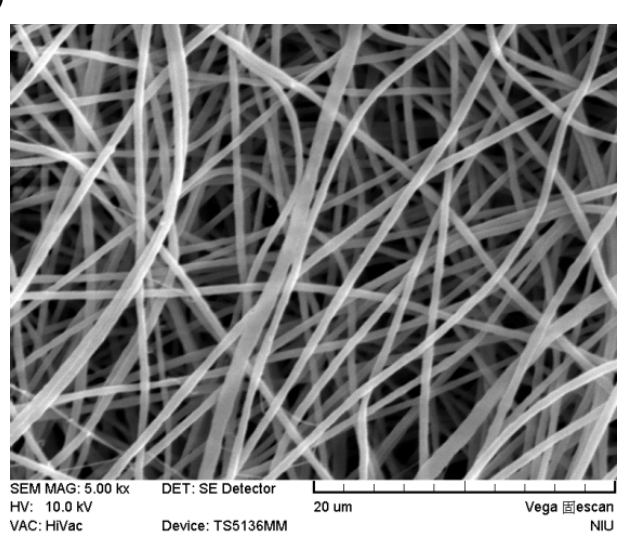

(c)

Figure 9. (a) Effect of flow rate on the fiber diameter of the SF/PCL/CS nanofibers, (b) SEM micrograph at $0.3 \mathrm{~mL} / \mathrm{h},(\mathrm{c}) \mathrm{SEM}$ micrograph at $0.4 \mathrm{~mL} / \mathrm{h}$. 


\subsection{Effect of Applied Voltage on Fiber Diameter}

In general, the operating applied voltage must exceed the minimum threshold applied voltage before the Taylor cone appears to form ultrafine nanofibers [23]. As shown in Figure 10, the results revealed that the average fiber diameter significantly decreased from $440.69 \pm 105.47 \mathrm{~nm}$ to $208.27 \pm 55.76 \mathrm{~nm}$ as the applied voltage increased from 15 to $25 \mathrm{kV}$. This result could be explained by the force imbalance between the repulsive Columbic force and the contracting viscoelastic force. With the increasing voltage, the intrinsic equilibrium became difficult to restore when the fibers were collected on the metal rod accompanied by the charge transfer.

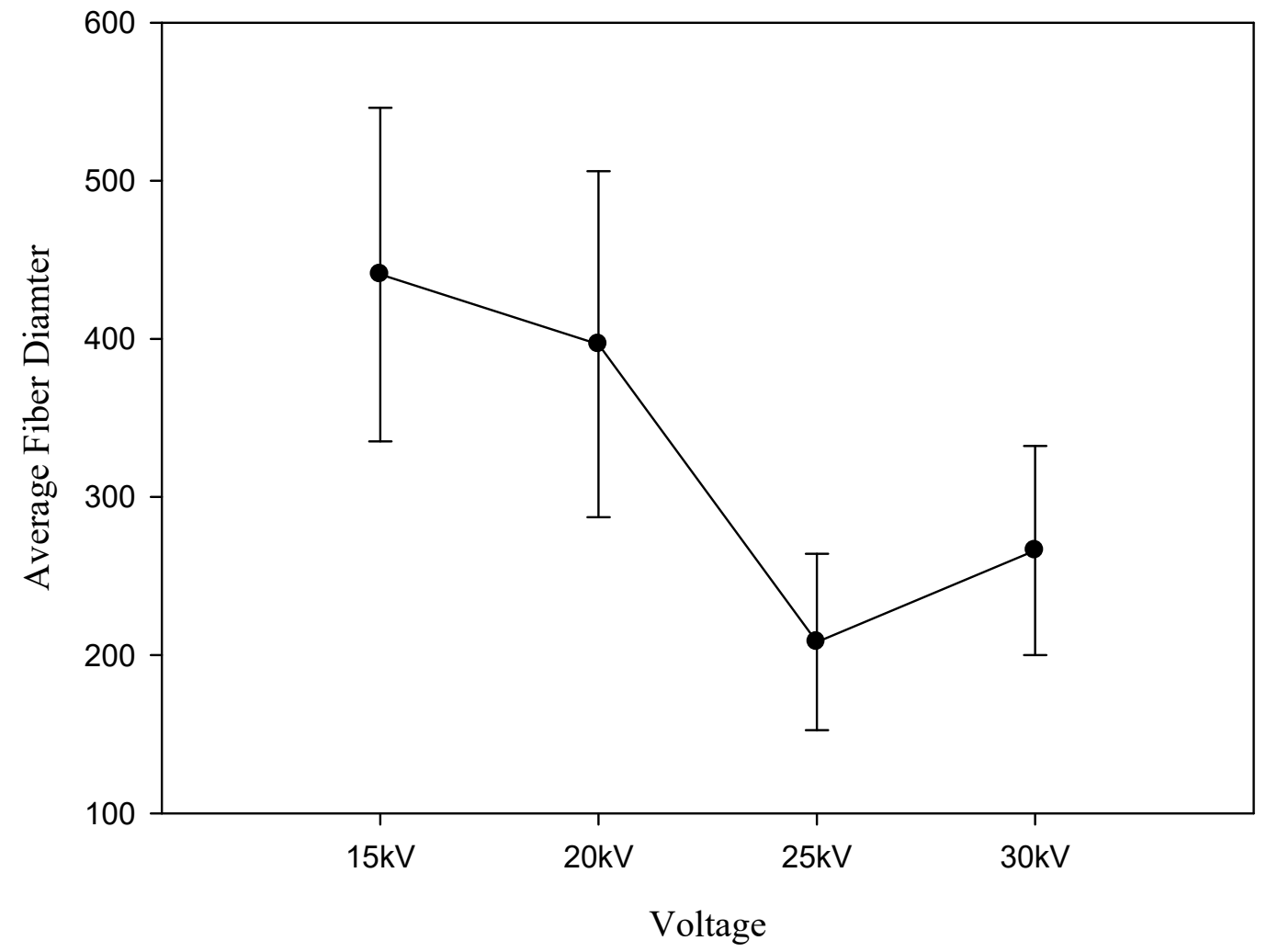

Figure 10. Effect of applied voltage on fiber diameter.

\section{Conclusion}

SF, PCL, and CS were blended in different concentrations and compositions and were evaluated for their fiber diameter to examine the optimum values for nanofibers. The $\mathrm{S} / \mathrm{N}$ analysis via the Taguchi experimental design showed that the ratio of SF to PCL was the most influential parameter on the fiber diameter. A smooth and uniform distributed SF/PCL/CS nanofiber with a fiber diameter of $170.0 \mathrm{~nm}$ was synthesized at the optimal parameters of a 1:2 ratio of silk fibroin to polycaprolactone, a $0.5 \%$ chitosan addition, a $0.3 \mathrm{~mL} / \mathrm{h}$ rate of advancement, and an operating voltage of $25 \mathrm{kV}$. The SF/PCL/CS (under optimal conditions) with a WVTR of approximately $4768.71 \mathrm{~g} / \mathrm{m}^{2} \cdot 24 \mathrm{~h}$ could maintain the optimal moisture content for the proliferation and function of cells and fibroblasts. The EWC of the SF/PCL/CS nanofiber was increased from $500 \%$ to $950 \%$ by increasing the chitosan additions from $0.25 \%$ to $1.00 \%$ and was significantly higher than the YY0148-2006 standard for medical dressings. The porosity of the nine samples $\left(\mathrm{L}_{9}\left(3^{4}\right)\right)$ of SF/PCL/CS in this study was more than $80 \%$ and was significantly higher than that of the pure PCL scaffolds. According to SEM and the appropriate porosity of the SF/PCL/CS nanofiber, it was considered to have great potential for skin tissue engineering due to its interconnected pore network and suitable WVTR. 
Author Contributions: Project administration, M.-F.L.; Supervision, H.-W.C. All authors have read and agreed to the published version of the manuscript.

Funding: This research was supported in part by grant MOST 107-2221-E-197-001-MY2 from the Ministry of Science and Technology, Republic of China.

Conflicts of Interest: The authors declare no conflict of interest.

\section{References}

1. Ayutsede, J.; Gandhi, M.; Sukigara, S.; Micklus, M.; Chen, H.-E.; Ko, F. Regeneration of Bombyx mori silk by electrospinning. Part 3: Characterization of electrospun nonwoven mat. Polymer 2005, 46, 1625-1634. [CrossRef]

2. Yao, Y.; Wang, J.; Cui, Y.; Xu, R.; Wang, Z.; Zhang, J.; Wang, K.; Li, Y.; Zhao, Q.; Kong, D. Effect of sustained heparin release from $\mathrm{PCL} / \mathrm{chitosan}$ hybrid small-diameter vascular grafts on anti-thrombogenic property and endothelialization. Acta Biomater. 2014, 10, 2739-2749. [CrossRef]

3. Dias, J.R.; Baptista-Silva, S.; Sousa, A.; Oliveira, A.L.; Bártolo, P.J.; Granja, P.L. Biomechanical performance of hybrid electrospun structures for skin regeneration. Mater. Sci. Eng. C 2018, 93, 816-827. [CrossRef]

4. Avsar, G.; Agirbasli, D.; Agirbasli, M.A.; Gunduz, O.; Oner, E.T. Levan based fibrous scaffolds electrospun via co-axial and single-needle techniques for tissue engineering applications. Carbohydr. Polym. 2018, 193, 316-325. [CrossRef] [PubMed]

5. Surucu, S.; Sasmazel, H.T. Development of core-shell coaxially electrospun composite PCL/chitosan scaffolds. Int. J. Biol. Macromol. 2016, 92, 321-328. [CrossRef] [PubMed]

6. Pakravan, M.; Heuzey, M.-C.; Ajji, A. A fundamental study of chitosan/PEO electrospinning. Polymer 2011, 52, 4813-4824. [CrossRef]

7. Narayanan, G.; Gupta, B.S.; Tonelli, A.E. Enhanced mechanical properties of poly( $\varepsilon$-caprolactone) nanofibers produced by the addition of non-stoichiometric inclusion complexes of poly( $\varepsilon$-caprolactone) and $\alpha$-cyclodextrin. Polymer 2015, 73, 321-330. [CrossRef]

8. Yang, X.; Fan, L.; Ma, L.; Wang, Y.; Lin, S.; Yu, F.; Pan, X.; Luo, G.; Zhang, D.; Wang, H. Green electrospun Manuka honey/silk fibroin fibrous matrices as potential wound dressing. Mater. Des. 2017, 119, 76-84. [CrossRef]

9. Lin, L.; Zhu, Y.; Li, C.; Liu, L.; Surendhiran, D.; Cui, H. Antibacterial activity of PEO nanofibers incorporating polysaccharide from dandelion and its derivative. Carbohydr. Polym. 2018, 198, 225-232. [CrossRef] [PubMed]

10. Ahmed, R.; Tariq, M.; Ali, I.; Asghar, R.; Khanam, P.N.; Augustine, R.; Hasan, A. Novel electrospun chitosan/polyvinyl alcohol/zinc oxide nanofibrous mats with antibacterial and antioxidant properties for diabetic wound healing. Int. J. Biol. Macromol. 2018, 120, 385-393. [CrossRef]

11. Zhang, D.; Karki, A.B.; Rutman, D.; Young, D.P.; Wang, A.; Cocke, D.; Ho, T.H.; Guo, Z. Electrospun polyacrylonitrile nanocomposite fibers reinforced with $\mathrm{Fe}_{3} \mathrm{O}_{4}$ nanoparticles: Fabrication and property analysis. Polymer 2009, 50, 4189-4198. [CrossRef]

12. Zhu, J.; Wei, S.; Patil, R.; Rutman, D.; Kucknoor, A.S.; Wang, A.; Guo, Z. Ionic liquid assisted electrospinning of quantum dots/elastomer composite nanofibers. Polymer 2011, 52, 1954-1962. [CrossRef]

13. Aslan, T.; Arslan, S.; Eyvaz, M.; Güçlü, S.; Yüksel, E.; Koyuncu, İ. A novel nanofiber microfiltration membrane: Fabrication and characterization of tubular electrospun nanofiber (TuEN) membrane. J. Membr. Sci. 2016, 520, 616-629. [CrossRef]

14. Jiang, L.; Tu, H.; Lu, Y.; Wu, Y.; Tian, J.; Shi, X.; Wang, Q.; Zhan, Y.; Huang, Z.; Deng, H. Spherical and rodlike inorganic nanoparticle regulated the orientation of carbon nanotubes in polymer nanofibers. Chem. Phys. Lett. 2016, 650, 82-87. [CrossRef]

15. Yao, Y.; Wei, H.; Wang, J.; Lu, H.; Leng, J.; Hui, D. Fabrication of hybrid membrane of electrospun polycaprolactone and polyethylene oxide with shape memory property. Compos. B. Eng. 2015, 83, 264-269. [CrossRef]

16. Rao, M.; Geng, X.; Liao, Y.; Hu, S.; Li, W. Preparation and performance of gel polymer electrolyte based on electrospun polymer membrane and ionic liquid for lithium ion battery. J. Membr. Sci. 2012, 399-400, 37-42. [CrossRef]

17. Narayanan, G.; Tekbudak, M.Y.; Caydamli, Y.; Dong, J.; Krause, W.E. Accuracy of electrospun fiber diameters: The importance of sampling and person-to-person variation. Polym Test. 2017, 61, 240-248. [CrossRef] 
18. Yu, W.-J.; Xu, S.-M.; Zhang, L.; Fu, Q. Morphology and mechanical properties of immiscible polyethylene/polyamide12 blends prepared by high shear processing. Chinese J. Polym. Sci. 2017, 35, 1132-1142. [CrossRef]

19. Park, Y.R.; Ju, H.W.; Lee, J.M.; Kim, D.-K.; Lee, O.J.; Moon, B.M.; Park, H.J.; Jeong, J.Y.; Yeon, Y.K.; Park, C.H. Three-dimensional electrospun silk-fibroin nanofiber for skin tissue engineering. Int. J. Biol. Macromol. 2016, 93, 1567-1574. [CrossRef]

20. Aznar-Cervantes, S.D.; Daniel, V.C.; Luis, M.O.; Cenis, J.L.; Abel, L.P.A. Influence of the protocol used for fibroin extraction on the mechanical properties and fiber sizes of electrospun silk mats. Mater. Sci. Eng. C 2013, 33, 1945-1950. [CrossRef]

21. Calamak, S.; Aksoy, E.A.; Ertas, N.; Erdogdu, C.; Sagıroglu, M.; Ulubayram, K. Ag/silk fibroin nanofibers: Effect of fibroin morphology on Ag+ release and antibacterial activity. Eur. Polym. J. 2015, 67, 99-112. [CrossRef]

22. Vaz, J.M.; Taketa, T.B.; Hernandez-Montelongo, J.; Chevallier, P.; Cotta, M.A.; Mantovani, D.; Beppu, M.M. Antibacterial properties of chitosan-based coatings are affected by spacer-length and molecular weight. Appl. Surf. 2018, 445, 478-487. [CrossRef]

23. Albetran, H.; Dong, Y.; Low, I.M. Characterization and optimization of electrospun $\mathrm{TiO}_{2} / \mathrm{PVP}$ nanofibers using Taguchi design of experiment method. J. Asian Ceram. Soc. 2015, 3, 292-300. [CrossRef]

24. Senthil, T.; Anandhan, S. Electrospinning of non-woven poly(styrene-co-acrylonitrile) nanofibrous webs for corrosive chemical filtration: Process evaluation and optimization by Taguchi and multiple regression analyses. J. Electrostat. 2015, 73, 43-55. [CrossRef]

25. Ryan, M.P.; Rea, M.C.; Hill, C.; Ross, R.P. An application in cheddar cheese manufacture for a strain of Lactococcus lactis producing a novel broad-spectrum bacteriocin, lacticin 3147. Appl. Environ. Microbiol. 1996, 62, 612-619. [CrossRef]

26. Duffy, G.; Whiting, R.C.; Sheridan, J.J. The effect of a competitive microflora, $\mathrm{pH}$ and temperature on the growth kinetics of Escherichia coli O157:H7. Food Microbiol. 1999, 16, 299-307. [CrossRef]

27. Rosengren, A.; Faxius, L.; Tanaka, N.; Watanabe, M.; Bjursten, L.M. Comparison of implantation and cytotoxicity testing for initially toxic biomaterials. J. Biomed. Mater. Res. A 2005, 75, 115-122. [CrossRef]

28. Izquierdo, R.; Garcia-Giralt, N.; Rodriguez, M.T.; Cáceres, E.; García, S.J.; Ribelles, J.L.G.; Joan, M.M.; Monllau, C.; Suay, J. Biodegradable PCL scaffolds with an interconnected spherical network for tissue engineering. J. Biomed. Mater. Res. A 2008, 85, 25-35. [CrossRef]

29. Mehrabani, M.G.; Karimian, R.; Rakhshaei, R.; Pakdel, F.; Eslami, H.; Fakhrzadeh, V.; Rahimi, M.; Salehi, R.; Kafil, H.S. Chitin/silk fibroin/ $\mathrm{TiO}_{2}$ bio-nanocomposite as a biocompatible wound dressing bandage with strong antimicrobial activity. Int. J. Biol. Macromol. 2018, 116, 966-976. [CrossRef]

30. Zhou, J.; Cao, C.; Ma, X. A novel three-dimensional tubular scaffold prepared from silk fibroin by electrospinning. Int. J. Biol. Macromol. 2009, 45, 504-510. [CrossRef]

31. Qi, R.; Shen, M.; Cao, X.; Guo, R.; Tian, X.; Yu, J.; Shi, X. Exploring the dark side of MTT viability assay of cells cultured onto electrospun PLGA-based composite nanofibrous scaffolding materials. Analyst 2011, 14, e1800403. [CrossRef] [PubMed]

32. Sutasinpromprae, J.; Jitjaicham, S.; Nithitanakul, M.; Meechaisue, C.; Supaphol, P. Preparation and characterization of ultrafine electrospun polyacrylonitrile fibers and their subsequent pyrolysis to carbon fibers. Polym. Int. 2006, 55, 825-833. [CrossRef]

33. Jacobs, V.; Anandjiwala, R.D.; Maaza, M. The influence of electrospinning parameters on the structural morphology and diameter of electrospun nanofibers. J. Appl. Polym. Sci. 2010, 115, 3130-3136. [CrossRef]

34. Jia, Y.-T.; Gong, J.; Gu, X.-H.; Kim, H.-Y.; Dong, J.; Shen, X.-Y. Fabrication and characterization of poly (vinyl alcohol)/chitosan blend nanofibers produced by electrospinning method. Carbohydr. Polym. 2007, 67, 403-409. [CrossRef]

35. Vrieze, S.D.; Westbroek, P.; Camp, T.V.; Clerck, K.D. Solvent system for steady state electrospinning of polyamide 6.6. J. Appl. Polym. Sci. 2010, 115, 837-842. [CrossRef]

36. Da Silva, L.P.; De Britto, D.; Seleghim, M.H.R.; Assis, O.B.G. In vitro activity of water-soluble quaternary chitosan chloride salt against E coli. World J. Microbiol. Biotechnol. 2010, 26, 2089-2092. [CrossRef]

37. No, H.K.; Park, N.Y.; Lee, S.H.; Meyers, S.P. Antibacterial activity of chitosans and chitosan oligomers with different molecular weights. Int. J. Food Microbiol. 2002, 75, 65-72. [CrossRef] 
38. Li, S.; Li, L.; Guo, C.; Qin, H.; Yu, X. A promising wound dressing material with excellent cytocompatibility and proangiogenesis action for wound healing: Strontium loaded Silk fibroin/Sodium alginate (SF/SA) blend films. Int. J. Biol. Macromol. 2017, 104, 969-978. [CrossRef]

39. Someswararao, M.V.; Dubey, R.S.; Subbarao, P.S.V.; Singh, S. Electrospinning process parameters dependent investigation of $\mathrm{TiO}_{2}$ nanofibers. Results Phys. 2018, 11, 223-231. [CrossRef]

40. Kostina, N.Y.; Blanquer, S.; Pop-Georgievski, O.; Rahimi, K.; Dittrich, B.; Höcherl, A.; Michálek, J.; Grijpma, D.W.; Rodriguez-Emmenegger, C. Zwitterionic functionalizable scaffolds with gyroid pore Architecture for tissue engineering. Macromol. Biosci. 2019, 19, e1800403. [CrossRef]

41. Jin, H.-J.; Fridrikh, S.V.; Rutledge, G.C.; Kaplan, D.L. Electrospinning Bombyx mori silk with poly(ethylene oxide). Biomacromolecules 2002, 3, 1233-1239. [CrossRef] [PubMed]

(C) 2020 by the authors. Licensee MDPI, Basel, Switzerland. This article is an open access article distributed under the terms and conditions of the Creative Commons Attribution (CC BY) license (http://creativecommons.org/licenses/by/4.0/). 